Draft. Not for quotation. Comments welcome.

\title{
Strategic Segmentation in Frontline Services: Matching Customers, Employees, and Human Resource Systems
}

\author{
Forthcoming \\ International Journal of Human Resource Management
}

Revised October 20, 1999

\author{
ROSEMARY BATT \\ Assistant Professor \\ Department of Human Resource Studies \\ New York State School of Industrial Labor Relations \\ Cornell University \\ Ithaca, NY 14863-3901 \\ Tel: (607) 254-4437 \\ Fax: (607) 255-18 \\ E-mail: rb41@cornell.edu
}




\section{Acknowledgements}

This paper is based on a multi-year research project on the Telecommunications Services

Industry, funded by the Alfred P. Sloan Foundation and carried out in conjunction with Harry C. Katz and Jeffrey Keefe. This paper was initially presented at the workshop "The Service Workplace,” Wharton School of Business, University of Pennsylvania, Philadelphia, PA, October 16-17, 1998. The author thanks Steve Frenkel, Chip Hunter, Harry Katz, Jeffrey Keefe, and Gil Preuss for reading the manuscript and providing very helpful suggestions. 


\begin{abstract}
This paper examines variation in the use of high involvement work practices in service and sales operations. I argue that the relationship between the customer and frontline service provider is a central feature that distinguishes production-level service activities from manufacturing. In particular, through strategic segmentation, firms are able to segment customers by their demand characteristics and to match the complexity and potential revenue stream of the customer to the skills of employees and the human resource system that shapes the customer-employee interface. Unlike manufacturing, where high involvement systems have emerged in a wide variety of product markets, therefore, service organizations are likely to use high involvement systems only to serve higher value-added customers because of the high costs of these systems and the labor-intensive nature of services. Data from a nationally random sample of 354 call centers in U.S. telecommunications documents this pattern: from classic mass production approaches for back office workers and increasingly for front office residential service agents, to greater involvement for small business service providers, and high involvement practices for middle market service agents.
\end{abstract}




\section{Strategic Segmentation in Frontline Services: Matching Customers, Employees, and Human Resource Systems}

\section{Introduction}

Cumulative research over three decades has documented the use of "high performance" or "high involvement” work systems (HIWS) in a variety of national settings (e.g., Womack, et. al., 1990; Appelbaum and Batt, 1994), industries (e.g., Ichniowski et. al., 1996), and organizations (Becker and Gerhart, 1996). High involvement systems have been defined in various ways, but generally include three dimensions: high relative skill requirements, jobs designed to provide the opportunity to use those skills in teams or in collaboration with other workers, and an incentive structure to induce discretionary effort (Appelbaum et. al., 2000). Classic mass production approaches to work organization, by contrast, emphasize low skill requirements, narrow jobs with low discretion, and few incentives for discretionary effort.

An important debate in this literature is whether high involvement systems are universally beneficial (e.g., Pfeffer, 1998). Do high involvement systems constitute "best practices" that are likely to be adopted across a wide range of industries and occupations? In this paper I address the debate by examining variation in the use of high involvement systems in service and sales operations. Under what conditions and why do firms use high involvement work practices for service and sales delivery? What types of sales operations are more likely to adopt them?

Because most empirical research on this question has been conducted among blue collar workers, we now have a reasonable understanding of the relationship between these work systems and performance outcomes in manufacturing. First, we there is growing evidence that high involvement systems do produce better performance in a wide range of manufacturing settings (e.g., Ichniowski et. al., 1996). Second, researchers have found that the logic or 
rationale behind performance gains varies widely across different organizations and industry settings. For example, in the apparel industry, the key performance gain is "through-put time": it is the multi-skilling in self-managed teams that allows firms to improve throughput time and to compete on the basis of quick response to changes in market demand (Appelbaum et. al., 2000; Dunlop and Weil, 1999). In the steel industry, by contrast, the huge capital outlays in plant and equipment mean that "machine uptime" determines competitive advantage (Ichniowski et. al., 1997); it is particularly the communication and coordination of workers across miles of steel mills that leads to better machine utilization (Appelbaum et. al., 2000).

By contrast, our understanding of the costs and benefits of high involvement systems in service activities is relatively undeveloped, both because less research has been undertaken and because the range of variation in service organizations and occupations is much greater than in manufacturing. For example, the "service sector" covers 80 percent of the U.S. workforce (Monthly Labor Review, 1998), from janitors and home health care workers to lawyers, doctors, and investment bankers. To understand the use of high involvement work in services, therefore, it is particularly important to disaggregate the data into different industries, occupations, and sub-occupations. While aggregate survey data show that a substantial minority of U.S. service workplaces have adopted some innovative work practices -- such as total quality, problemsolving groups, or self-managed teams (e.g., Osterman, 1994, 2000; Lawler, et. al., 1995) -- we do not know the distribution of these practices.

For example, while Osterman (1994) found that 55 percent of service establishments reported using self-managed teams, Hunter (1999a) found much lower levels in his survey of low-skilled bank tellers. Perhaps high involvement practices are concentrated among higher skilled service occupations. Recent cross-national research, for example, has documented wide 
variation in work systems across distinct occupational groups in the service sector, from highly regimented systems for low-skilled customer service workers to "empowered" systems for knowledge workers such as systems developers (e.g., Frenkel, et. al., 1999). Similarly, Herzenberg, et. al. (1998) developed a taxonomy of service work from tightly rationalized systems for low skilled workers, to semi-autonomous systems for moderately skilled, and autonomous systems for technical and professional workers. Thus, our aggregate surveys may be capturing the "high involvement" practices of technical and professional employees, rather than production-level service workers. Researchers and practitioners, however, have been interested in high involvement work systems precisely because of their potential to enhance, or "quasi-professionalize" the work behavior and attitudes of production-level workers.

This paper contributes to the literature on high involvement work systems by examining the rationale for their use and the extent of variation in adoption in service operations -specifically, frontline customer service and sales activities. This type of service work, best described as "interactive service work" (Leidner, 1993), may be conducted in face-to-face transactions, in telephone-mediated transactions, or through other electronic media. Increasingly, these operations are carried out in call centers, where employees interact with customers via telephones and computers to handle service, sales, and billing inquiries. Call centers are a useful setting to examine high involvement practices because these offices have come to be viewed as proto-typical "white collar factories" of the $21^{\text {st }}$ century. Recent research suggests that there is wide variation in work organization and human resource practices (e.g., Batt and Keefe, 1999;), from highly routinized mass production enterprises (e.g., Greenbaum, 1995; Taylor and Bain, 1999; Fernie and Metcalf, 2000) to skilled and entrepreneurial environments (Herzenberg, et. al., 1998; Frenkel et. al., 1999). Also, the use of call centers has 
increased dramatically in most industries and advanced economies because companies find them an efficient vehicle for managing the customer interface. They are also of strategic importance where companies seek to compete by building a loyal customer base.

To examine this question, I draw on a multiyear study of service and sales channels in the U.S. telecommunications services industry. This setting is instructive because it represents a more advanced case of service sector restructuring and one that has already influenced the approaches taken in other advanced economies. That is, in contrast to the auto and other manufacturing industries where producers worldwide sought to emulate Japanese lean production (Womack et. al., 1990; Liker et. al., 1999), many countries have looked to the U.S. as a model for restructuring telecommunications because historically it led the world in new technologies and in the early 1980s it led the deregulation movement (Katz, 1997). Increased competition from deregulation has affected this industry in ways that are parallel to the impact of globalization in manufacturing. In response to deregulation, former U.S. telecommunications monopolists undertook massive restructuring and introduced new work practices to compete on quality, price, and service (Keefe and Batt, 1997). Since the 1980s, most countries around the globe have deregulated and privatized their publicly-regulated telephone monopolies and are searching for ways to reduce costs and enhance service.

In addition, compared to other service industries, telecommunications is a likely candidate for adopting high involvement practices for several reasons. As a "high tech" industry, it has always employed a high skilled workforce and invested heavily in training and technological innovation. It continues at the forefront of engineering advanced information systems. The prior existence of a relatively high-skilled workforce coupled with the use of advanced information systems makes the use of high involvement systems more feasible. 
Moreover, it is a critical industry for information-based economies, and typically employs 1-2 percent of the workforce (Katz, 1997). All countries are looking to this industry to provide high quality, low cost information services as inputs into all other sectors of the economy.

In the next section, I review the relevant literature on competing approaches to organizing service work: mass production versus high involvement systems. I discuss the competing "production logics" of these two approaches, and highlight how they are similar or different in manufacturing and service settings. Then, I review the evidence on variation in use of high involvement practices in services by drawing on a unique nationally representative sample of 354 call centers in U.S. telecommunications firms. This is followed by a discussion of the implications of the U.S. case for other countries, industries, and service activities.

As a preview, my argument may be summarized as follows. The relationship between the customer and frontline service provider is a central feature that distinguishes productionlevel service activities from manufacturing. As a result, unlike manufacturing, the customerworker interface is a significant factor in defining the organization of work and human resource practices in services. As marketing has become more sophisticated over the last two decades, companies have become adept at segmenting customers by their characteristics and potential revenue stream. This technique, known as "strategic segmentation" (Keltner, 1998) is enabled by advanced information systems and process redesign, and has diffused widely over the 1990s. It allows companies to match the demand characteristics and potential value of the customer to the characteristics of the workforce and to the human resource systems that shape the customerworker interface. Unlike manufacturing where high involvement systems have emerged in a wide variety of product markets, therefore, I argue that services organizations are likely to invest in high involvement practices only to serve higher value-added customers because of the high 
costs of these systems and the labor-intensive nature of services. The data from service delivery systems in U.S. telecommunications documents this pattern: from classic mass production approaches for back office workers (e.g., telephone operators), and increasingly for front office residential service agents, to greater involvement for small business service providers and high involvement practices for those serving larger or middle market business customers.

\section{Mass Production versus High Involvement in Services}

Management theorists have developed two competing models of service management that are the functional equivalent of mass production and high involvement models found in the manufacturing literature. The use of these approaches differs between manufacturing and services, however, because of fundamental differences in the nature of goods and service production $^{1}$. For purposes of this discussion, the central difference hinges on the role of the customer in production, which introduces greater uncertainty and variability into the process.

The application of mass production concepts to services grew as an attempt by operations researchers to solve the problem of historic low productivity growth in services. A leading exponent, Levitt $(1972,1976)$, advocated simplification of tasks, clear division of labor, the use

of labor-substituting technology, and low levels of employee discretion. Firms hire workers with low skills and low discretion at low pay. Information technology is used to automate processes and electronically monitor workers performance. This model of rationalization was successfully applied to "back office" operations such as data processing and operator services, but found limited application to the "front office" (or customer service operations) because of the uncertainty introduced by the customer. While engineering systems can rationalize the behavior of workers, the customer is outside of the production process, and therefore, introduces much greater uncertainty into the system. Researchers in management science have attempted to 
reduce this uncertainty by treating customers as "partial employees" or using marketing and product standardization to reduce customer variation (e.g., Czepiel, Solomon, and Surprenant, 1986; Mills, 1986; Bowen, 1986; Zeithaml, Parasuraman, and Berry, 1990). Significantly, then, organizing service work as a production line means not only that work routines of employees are standardized, but the options for customers are also standardized. The work system, therefore, requires the adoption of a standardized approach to customers as well. Firms who wish to compete on high volume, low cost standardized service offerings are likely to adopt this approach organizing service work.

An alternative view, based on building loyal customers through quality service, emerged in the 1980s on the heals of the total quality movement (e.g., Zimmerman and Enell, 1988). A slew of management books prescribed solutions for improving quality and "focusing on the customer” (e.g. Albrecht and Bradford, 1989; Davidow and Uttal, 1989; Zemke and Schaff, 1989; Heskett, Sasser, and Hart, 1990; Schneider and Bowen, 1995). Articles on service management also began appearing regularly in the Harvard Business Review and the Sloan Management Review ${ }^{2}$.

A number of researchers then developed models for competing on quality and customization through high involvement practices (e.g., Bowen and Schneider, 1988; Schlesinger and Heskett, 1991; Bowen and Lawler, 1992; Heskett et. al., 1997). Schlesinger and Heskett (1991), for example, distinguish between a "cycle of failure" (the mass production model) and a "cycle of success" (high involvement services). They argue that the mass production model leads to a cycle of failure because narrow, functional jobs lead workers to experience boredom, low morale, and indifference to customers, resulting in poor service. Customers' dissatisfaction "fuels further decreases in employee satisfaction," which leads to 
higher employee turnover, deterioration of service, and customer turnover. Customer defection creates a cycle of failure in which firms increasingly focus on "hard selling" to replenish their lost customer base.

Under the “cycle of success,” (Schlesinger and Heskett, 1991) or "capability" (Heskett, et. al., 1997), firms hire skilled employees at higher pay and create jobs with greater breadth and discretion. Workers use information technology as a resource rather than a monitoring device. Satisfied workers provide better service, and satisfied customers, in turn, improve employee motivation. Other versions of this approach include Ulrich et. al. (1991), and Bowen and Lawler (1992, 1995), who distinguish between the control and empowerment models, as exemplified by UPS and Federal Express respectively.

A similar set of arguments is found in the literature on "relationship management” (e.g., Gutek, 1995; Keltner, 1995; Keltner and Finegold, 1996), or the “case management approach” (Davenport and Nohria, 1994), but with less explicit attention to employee satisfaction as a causal factor. Relationship management allows employees to provide "one-stop-shopping,” with good service "bridging to sales". The bridge to sales occurs because the long-term relationship with a customer allows the frontline employee to know what that customers needs. Employees build a data base of customer information and are able to both serve the customer better and know what sales opportunities exist, maximizing service and sales together. Highly trained individuals use their skills and analytical capacity to fit services to meet customer demand. They use their unique understanding of the service offerings and capabilities of the firm and the potential needs of customers to generate new demand. Evidence in support of this model comes from Keltner (1995), who argued that German banks’ outperformed U.S. banks in the 1980s by adopting a strategy of relationship banking coupled with highly skilled and trained employees. 
In sum, the literature on alternative work systems in services has debated the relative merits of rationalizing service delivery through standardized work routines and automation or customizing service provision through high involvement human resource practices. Both approaches appear quite viable. On the one hand, in contrast to manufacturing where mass production systems were widely adopted by mid-century, their use in services was relatively undeveloped until the 1970s. Moreover, because of on-going low productivity growth in services, mass production approaches continue to be appealing and continue to expand. For example, a 1990 management text noted, "Led by franchisers, more and more service firms are standardizing their operating procedures. Costs are reduced as a result of economies of scale, and bottlenecks become easier to identify and eliminate. Quality control is aided by increased conformance to clear specifications. And standardization of job tasks allows the organization to recruit relatively unskilled, inexpensive workers who require only limited training to perform highly routinized tasks” (Lovelock, 1990:352).

In addition, in the 1990s, the combined use of process reengineering coupled with advanced information systems has made it possible to expand automation from the back office (typists, data processors, operators) to the front office (customer service and sales employees). One-800 telephone numbers, automatic call distribution and routing systems, voice recognition systems, etc., have made it possible to achieve dramatic improvements in scale economies through centralized distribution channels serving wider geographic areas. Local customer service agents who used to provide personal service to repeat customers now work in large "call centers” providing remote service through 1-800-numbers. Examples include call centers in telemarketing operations, banking (Hunter, 1998a), telecommunications (Batt and Keefe, 1999), and insurance (Keltner and Jenson, 1998). While research on information technology in the 
1980s found no increase in productivity associated with investments in IT (e.g., NRC, 1994), more recent studies are beginning change that view (e.g., Brynjolfson and Yang, 1996). Clearly then, there are enormous productivity gains to be made through process reengineering coupled with the use of advanced information systems and the routinization of service work.

On the other hand, companies worry about the loss of loyal customers. A good example comes from the marketing battle between MCI and AT\&T in which customers regularly switched from one long distance carrier to another to take advantage of the latest deals for "Friends and Families" or "True Rewards". There is growing evidence that the high involvement model reduces the costs of employee turnover, customer turnover, and low quality and low productivity associated with new employees. Satisfied, loyal customers buy more, buy more value-added services, and are willing to pay a premium for reliability and quality (Reichheld, 1993, 1996; Jones and Sasser, 1995).

\section{Who Adopts High Involvement Practices: The Role of Strategic Segmentation}

These models provide two opposing approaches to business strategy and work organization in services: one that focuses on high volume, low cost, standardized transactions and rationalized production, and one that builds sales revenues through customization, good service, long-term relations with customers, and high involvement work practices. They do not explain, however, who is likely to adopt alternative approaches, nor who is likely to adopt a combination of approaches between these two extremes.

This is where the characteristics and potential revenue stream of the customer currently play a significant role in shaping managerial choice of business strategy and human resource practices. Whereas in the past, service providers used fairly undifferentiated approaches to customers -- treating all customers more or less equally -- advances in marketing have shown 
how service and sales channels can be managed more strategically. Until the 1970s, for example, most service marketing strategies were conceptualized in terms of specific industry or product characteristics (Lovelock, 1983). Since then, research in marketing has adopted alternative frameworks for targeting customers, and segmentation by customer characteristics has emerged as a critical organizing principle (e.g., Ames and Hlavacek, 1989; Day, 1990; Whitely, 1991;

Kotler, 1994). A succinct statement of the principle comes from Pine (1993:223):

"The basics of market-driven management are to segment, target, position, and create. Segment your customers and potential customers into meaningful groups that have homogeneous needs within each group. Target those market segments that (1) match the capabilities of the firm and (2) have the highest business potential (generally done in terms of revenue, profit, or return on assets). Position your firm and its existing and potential products and services in each of the target segments; positioning provides the reason for being, the unique differentiating characteristics that would cause targeted customers to purchase from you. Finally, create the products and services that meet the requirements of your target market segments.”

Using the logic of strategic segmentation, the most profitable approach to service delivery is to segment service activities according to the potential revenue stream of the customer. In his studies of commercial banking and insurance, for example, Keltner (1998) identified four approaches that vary according to customer characteristics and ability to pay: automated service delivery, mass customization, bundling of service products, and customization of specialized services. Similar categories are found in telecommunications services. At the low end, where there is little or no interaction between customers and providers, firms are likely to focus on cost minimization and take full advantage of the scale economies inherent in automated 
systems. The classic example of mass production in the telecommunications industry is operator services, which underwent successive generations of automation from the 1920s on. Since the 1980s, advances in information technologies and voice recognition systems have further automated and rationalized operator work (Kohl, 1993). As a result of this automation, operators represented $60 \%$ of the U.S. telecommunications workforce in the 1930 s, 45 percent in the 1950s, 14 percent in the 1980s, and less than 10 percent in the 1990s (Keefe and Batt, 1997). Beyond the back office, telecommunications firms have differentiated customers into residential, small business, middle market business, and large businesses, the latter of which usually cover national and international accounts (Batt and Keefe, 1999). In one long distance company, for example, separate service centers focus on residential customers and four successive tiers of business clients: accounts up to $\$ 500$ per month; those between $\$ 500$ and $\$ 3,000$; those between $\$ 3,000$ and $\$ 5,000$; and those larger than $\$ 5,000$. Notably, the unit costs of establishing service for these customers are similar: telecommunications firms must build and maintain a network infrastructure that serves all customers; and the last mile to the customer's premise is the most costly portion of the network. Once the line is established, profitability depends on how many additional features or more complex service offerings can be billed.

Here, each of these segments varies in their potential revenue stream and demand characteristics. That is, potential revenue and level of service complexity are highly correlated. Residential customers demand basic phone service; companies have sought to increase the revenue stream through enhancements such as call waiting, call forwarding, and more recently, data and internet offerings, and second lines to the home. Small businesses, on average, demand more lines and a greater number of service offerings, such as internal call transfer capability and data transmission; the products themselves, however, are not significantly more complex than 
those offered to the home. Moreover, the line between a high-end retail where residential customers have home offices, and small mom and pop businesses, is often blurred. By contrast, the differences between these two segments and the demands of middle market businesses are quite substantial. The larger the business operations, the greater the demand for product bundling, more complex products, and more customization -- for example, private branch exchange (PBX) systems and local area networks (LANs) to handle internal video, voice, and data transactions.

While this discussion highlights variation in complexity across segments, it is not meant to suggest that serving residential customers is "low skilled" work. Even at this level, employees must be skilled in several software packages and have negotiating skills to deal with tough customers. In the mass market, for example, employees are much more likely to have to deal with irate customers or investigate cases of fraud, in which customers attempt to get telephone service when they have been cut off for failure to pay their bills. Residential service reps must be quite sophisticated in their knowledge of information systems and manipulation of databases to retrieve the necessary information in cases such as these.

Once customers have been segmented by their potential revenue and demand characteristics, firms are able to select a workforce with the level of skills and education appropriate to the complexity of the services being offered and the extent to which the business seeks to build a relationship approach to the customer segment. It is not only the matching of customers to employees that matters, however. It also matters that the employees have the opportunity and incentives to manage the customer interface in a way that "fits" the business strategy. In the language of strategic human resource management (e.g., Dyer, 1986; Jackson and Schuler, 1987; Wright and McMahan, 1992 Truss and Gratton, 1994), there should be a fit 
between business and human resource strategy as well as an "internal coherence" among the components that make up the human resource system. Together, these are likely to produce better performance.

In service delivery, this matching of customer value to investment in human resource systems makes economic sense because of the labor-intensive nature of services and the high upfront and on-going costs associated with high involvement work systems. In manufacturing, where labor costs are often only ten percent of total costs, it is economically rational for firms to invest more in human resources in order to take full advantage of investments in new technology. In service operations, by contrast, labor still comprises 60 percent of costs, and labor productivity continues to grow at less than one percent annually. Despite the vision of high involvement and quality service, therefore, reducing labor costs continues to be a major priority in services, particularly in price-conscious mass markets. Put simply, for low margin customers, the costs of high involvement work systems are likely to be prohibitive; but for high value-added customers, relationship management via high involvement work systems has a high payoff.

The logic of customer segmentation in services, therefore, suggests a fairly straightforward relationship between the choice of work system and the potential revenue stream of the customer, as depicted in Figure 1.

\section{[insert Figure 1 here]}

One way of viewing this continuum in the use of high involvement work systems is that they are a means of "quasi-professionalizing" the workforce. As employees move from simple to more complex transactions and serve more sophisticated and value-added customers, they gain more skills and opportunity to assume independent judgement and responsibility for customers. 
At the very high end, for national corporate accounts, for example, firms employee collegeeducated, dedicated account executives that may be described as independent professionals. This conceptualization is consistent with that Herzenberg et. al. (1998) and Frenkel et al. (1999), who provide taxonomies of work systems from highly rationalized to empowered or autonomous across occupational groups in services. The difference in this case is that I identify patterns of variation within an industry and occupation, and link these patterns to business strategies based on customer segmentation.

\section{Strategic Segmentation in Telecommunications: Survey Results}

In order to examine whether customer segmentation is a useful lens for understanding choice of work systems in service and sales, I conducted a survey of a nationally representative sample of customer service establishments in 1998. The survey had a response rate of 53 percent, with a useable sample of 354 establishments. The telephone survey asked general managers a series of questions about the their customer base, and the attributes of their human resource systems. To link this research to that of high involvement work systems, I measured three dimensions of work systems: skill requirements, discretion and team collaboration at work, and incentive structures (pay, training, promotion, and employment security). However, unlike manufacturing, the role of the customer in work organization is critical, so I also measured various dimensions of the customer-provider interface -- both direct interaction and the extent of technology-mediated interaction. This definition is similar to that of Heskett et. al. (1997), who

include: a) how the provider interacts with the customer; b) how technology is used; c) skill level; d) discretion; and e) incentives, especially pay level.

The “core workforce” was defined as the group serving the establishment's largest segment of customers. Establishments were categorized into five groups: operator services 
( $\mathrm{N}=17)$, residential customers $(\mathrm{N}=106)$, small business customers $(\mathrm{N}=86)$, middle market customers ( $\mathrm{N}=68$ ); and those that had no strategy of targeting (they served anyone in their market) $(\mathrm{N}=77)$. Over three-quarters of the sample was pursuing a targeted customer strategy. The high value-added customers in the sample are primarily in the middle or regional market, with only a handful of centers serving national accounts. This is due to the fact that national account executives frequently work on their own, or are based in small offices inside larger office complexes. As a result, they usually do not work in the kind of stand-alone establishments that are listed in the Dun and Bradstreet listing that was used to randomly select the sample.

\section{Linking Customers to Workers: Strategic Segmentation and Technology}

Tables 1, 2, and 3 present the mean characteristics of work systems by the customer segment targeted. Table 1 covers the customer-employee interface; Table 2, skill levels, discretion, and team participation; and Table 3, incentives. Rather than describe all of the patterns in the data, I highlight the more salient ones in the discussion below. In general, the data show a consistent pattern of variation across customer segments in customer-provider interactions, in the use of technology to mediate that interaction, and in other dimensions of work organization. Beginning with Table 1, operator services is a useful anchor from which to examine the other work systems. In this classic mass production model, a typical operator serves 465 customers per day, the typical transaction (or cycle time of the job) lasts less than 1 minute, and only in rare instances do operators have face-to-face interactions with customers. Ninety-three percent of transactions are completed on-line, and over 50 percent of the establishments surveyed used scripted texts most or all of the time. With respect to technology, operators are electronically monitored two-thirds of the workday on average and spend 83 percent of their time simultaneously handling calls and manipulating computer databases. They 
typically use only one software package and receive about 3 emails a day from management regarding changes in products or procedures, suggesting high levels of standardization and little change or variation.

Compared to operator services, residential service agents must handle a wider range of customer inquiries that include setting-up new orders, adding enhanced features, arranging transfers, and handling billing issues. Because of added complexity and some opportunity to sell customized features, centers serving residential customers are unlikely to use scripted texts; and less than 10 percent of the residential centers in this study made use of scripts. Customerprovider relationships, however, are still highly transactional in this segment, with the typical agent serving 100 customers per day, averaging 6 minutes per call, and having face-to-face interactions less than 20 percent of the time.

The use of technology to mediate the service relationship is substantial, with reps spending three-quarters of their work-time simultaneously answering calls and manipulating online databases. They are electronically monitored about 50 percent of their time and complete nearly three-quarters of all transactions on-line. This means that in most cases, the service rep satisfies the customer's request by simultaneously interacting on the telephone and entering the appropriate information into existing databases. When the call is completed, the employee is ready to move immediately to the next caller in the queue. The systems are sufficiently automated that any service, sale, or billing inquiry can be input into the system at the front-end, and either handled automatically by the system software or forwarded to the appropriate department for execution. On average, residential reps manipulate 3.6 different types of software and receive 10 emails a day with product and procedural updates.

[Insert Table 1 here] 
This level of automation is the result of reengineering and advances in software systems in the 1990s. Prior to this, telephone companies were organized into functional silos and geographically based local customer service offices. Most of these offices were small -- 25, 50 or 75 employees located in geographically dispersed areas to serve local residences and businesses. Service occurred by phone or through walk-in customers, and differentiation by customer segment was undeveloped. Through organizational consolidation and process reengineering, firms were able to move to highly automated systems so that telephone service could be turned on remotely without the help of field technicians on the ground. Customer service was reorganized and consolidated into large "mega-centers," each focused on one particular clientele, and offering remote service through 1-800 numbers. Overhead and direct labor costs fell while customer response time improved. After reengineering at GTE in the mid1990s, for example, the percent of residential phone orders that were automatically established doubled, from 33\% in the past to 61\%. GTE consolidated 258 local work sites into 58 regionally based service centers. Similarly, AT\&T consolidated hundreds of customer service bureaus into six national mega-centers (Batt and Keefe, 1999). With re-engineering, the scale economies and benefits of automated systems could best be realized by consolidating offices into large megacenters; but with large scale operations, came less personalized, "remote servicing". An example comes from a service agent who experienced the consolidation of her local office into a reengineered call center of 600 workers:

"In the old office there were 70 or 80 of us....We knew the crews in the area, and could call them to find out where an installation stood. We knew where the cables were down because of weather problems.... everyone knew each other... we used to talk to each other about problems... there were more informal arrangements for getting things done. Now, there's 
reams of paper, too much to read, and new product information that comes online. If there's a service problem we can't handle, we're supposed to send a note to special reps, but we can't go and talk to them ourselves. Now we don't have to leave our desk for anything.... Now with 600 [workers], standardization is the rule.... We're supposed to adhere to our schedule [be on-line taking calls] 86 percent of the day."

She went on to explain that in the old system, employees often knew their customers, and developed personal relationships because service was local. Employees shared their tacit knowledge of products, customers, changing legal requirements, and complex legacy systems [computer systems used in the old Bell system] in their day-to-day interactions with each other. Service was slow, however, because the technology did not allow for automated order processing, which reduces through-put time [from the time of order to installation] from days to hours.

Thus process reengineering and consolidation has led to contradictory changes in customer service and the organization of work and human resource systems in residential services. Customers receive faster response time, but more standardized, less personalized service. For employees, there is greater information available through computerized databases, and the complexity of service offerings and new product information has increased. However, reengineering also has led to greater standardization of work rules and rationalization of processes that leave workers with less input and discretion in the handling of customers.

Reengineering and process standardization, however, have had limited applicability in higher value-added segments serving business customers in large part because the complexity of service offerings and interactions is less amenable to automation. To date, agents serving middle market customers retain a highly personalized system of interaction. For example, middle 
market service agents are much more likely to engage in relationship management. About half of the middle market centers in the sample use dedicated account managers -- that is, managers who are personally responsible for the accounts of particular customers. This approach is rarely or never used in residential or small business centers. In addition, middle market agents are about three times more likely than residential agents to have discretion over the types of customers and the number of customers they serve. This flexibility provides them with the opportunity to match their own strengths and abilities with customers of their choosing, and to target higher sales-generating customers.

On average, reps serving the middle market handle about 30 customers per day and almost half of their interactions are face-to-face on customer premises. They spend about half of their time simultaneously on the phone and on-line, and when they do so, the are able to complete only 40 percent of the transactions. They are electronically monitored only 20 percent of the time. The fact that they are unable to complete a large percentage of transactions on the phone indicates that there is more customization and complexity involved in meeting the customer's service requirements. Similarly, information technology is much more likely to be used as a resource in higher value-added segments. Middle market reps have access to about 7 software programs and data bases, and receive about 20 emails each day regarding new product features, changing rates and legal regulations, and new marketing campaigns.

Serving small business customers represents an intermediate case, one best characterized as "pseudo" relationship management in the words of Barbara Gutek (1995). Small business agents attempt to develop relationships with their customers by maintaining rich databases of information and using that information to provide bundled service offerings. However, they are usually not dedicated account executives, and the relationship exists more between the customer 
and organization (or brand) than with the individual service provider. Small business reps conduct roughly two-thirds their service transactions by phone, and one-third in face-to-face encounters with customers. They are electronically monitored about one-third of each day. When on-line, they are able to complete roughly two-thirds of their transactions while the customer waits. These characteristics suggest a mixed system, in which the "mom and pop" type businesses are handled in ways that are quite similar to residential customers; higher-end businesses require more on-site visits.

In addition, the workforce and organizational characteristics vary systematically across these distinct segments. For example, whereas in operator services, eighty-two percent of the workforce is female, this figure is 60 percent among small business reps and 46 percent among middle market reps. Organizationally, the residential centers in this study reflect the mega-center approach, with an average of 503 employees per center; by contrast, centers serving small business and middle market customers average 190 employees. Similarly, the average customer base for residential centers is four times that of centers serving middle market businesses. Finally, thirty-five 35 percent of the offices in operator services and 22 percent of those serving residential customers are unionized, but less than 5 percent of establishments in the middle market are covered by collective bargaining. ${ }^{3}$

\section{High Involvement Service Work: Skills, Discretion, Teams, and Pay}

Turning to the issue of skills, discretion, and the use of teams, these dimensions of work systems also vary significantly by customer segment, as reported in Table 2. Several indicators show systematic variation in the skill requirements of jobs. Formal education averages little more than a high school degree for operators, at least one year of post-secondary training for residential and small business reps, and 3 years of college for middle market reps. That is, in 
two thirds of the middle market establishments, the typical agent had a 4-year college degree. That figure was 15 percent in residential centers and 42 percent in small business centers. Also, the time it takes for the typical new hire to become qualified on the job varies significantly across the segments, from 13 weeks for operators and 17 weeks for residential reps, to 22 weeks for small business reps and almost 28 weeks for middle market reps.

In higher value-added customer segments, employers are also more likely to designate these jobs as "exempt" from U.S. wage and hour laws. Exempt status usually is associated with professional or managerial status and means that employees are not eligible for overtime pay. In this study, the survey excluded managerial employees, so the exempt status is associated with hiring a college-educated "professional". Some organizations also designate jobs as exempt when they are trying to quasi-professionalize the job and/or discourage unionization. Even in residential centers, for example, 13 percent of managers have adopted this strategy, although it is difficult to imagine why a professional workforce would be needed for the mass market. In middle market business centers, the percentage jumps to over 75 percent.

In daily work methods and schedules, the range of discretion again varies by segment served. In general, those serving the larger business market are at least twice as likely to have control over their daily tasks, work methods, pace of work, schedules, and use of technology. For example, for basic work routines (such as control over tasks, tools, procedures, and pace of work), between one quarter and one third of residential managers said that their employees had a lot or complete control; about twice as many managers of middle market centers reported their employees had discretion over these areas of work. It is noteworthy, however, that there are some areas in which even middle market agents have very little control. These areas include setting work objectives, revising work methods, and influencing the design or use of technology. 
[Insert Table 2 here]

Reflecting this variation in the job skill content and discretion of employees, median pay levels and the use of variable pay also vary significantly by customer segment, as reported in Table 3. Middle market reps earn 3.5 times more than operators and 2.5 times more than residential reps. Similarly, middle market reps have 3.3 times more pay at risk than operators, and 2.3 times more than residential agents. Median total compensation in 1998 (base pay, overtime, and benefits) was $\$ 35,708$ for residential reps and $\$ 78,390$ for middle market reps.

[Insert Table 3 here]

\section{Coherence and the Logic of High Involvement Systems}

The literature on high involvement systems argues that employers do best when they adopt a coherent set of practices. In this study, there are some areas where the use of high involvement practices do not vary systematically by customer segment served. These include the use of teams, and patterns of training, promotion, and employment security. For example, there is little variation with respect to the use of problem-solving groups -- meetings between employees and their superordinates on a regular basis as in total quality improvement teams. These forms of participation are typically associated with high involvement work systems in manufacturing. On average, ninety percent of all respondents reported using offline problemsolving groups. Our field research suggests, however, that while these are sometimes used to solve specific problems in call centers, they are often used as a motivational device to give employees who are tied to phone lines and computers a chance to get a break and go "offline." Thus, it is not clear whether these types of group meetings actually add value in terms of quality, productivity, or continuous improvement. 
The use of self-managed teams does vary by segment, with high use in higher valueadded business segments; but the differences are not statistically significant, indicating that there is great variation in their use within each segment.. It is likely that customers with more complex service needs should require greater use of teams composed of different specialists, and this is what Keltner and Jenson (1998) found to be true in their study of middle market business customers in commercial banking and insurance.

Training, promotion, and employment security also show less variation across customer segments, although even here, operator services stands out as distinctive. Leaving aside operator services, customer service reps in all other segments typically receive between 3 and 4 weeks of initial training and 2 weeks per year of on-going training. A substantial minority of employees (about 39\% on average) are promoted from within and a quarter or more have at least 10 years of company tenure. This pattern suggests that firms do not need to invest more in training at higher segment levels because they promote or hire employees with prior experience and training, a pattern also found by Keltner and Jenson in insurance and commercial banking (1998). They also found that the most significant on-going training occurred on the job, not formally.

With respect to employment security, operator, residential, and small business centers are significantly more likely than middle market centers to use part-time and temporary workers, reflecting greater cost pressures at lower value-added segments. Thus, while only 82 percent of operators are permanent, full-time workers, and 86 percent of residential reps, fully 95 percent of middle market reps are full-time and permanent. However, lay-off rates are generally high, and particularly so in three of the four segments. In operator, residential, and middle market centers, the number laid-off in the prior 5 years (1994-98) as a percent of the current workforce was between 24-28 percent, or roughly 5 percent annually. This provides a crude estimate of the 
amount of organizational change and downsizing that has occurred throughout the industry. It is surprisingly high that the industry has been growing dramatically in this period. Growth has been accompanied, however, by instability and churn, as competitive conditions have heightened and new entrants have entered the industry.

\section{Implications for International Human Resource Management}

In summary, the data in this study suggest that the majority of telecommunications establishments in the U.S. are pursuing a business strategy of strategic segmentation in their service and sales channels. Implementation of high involvement work practices varies systematically according the demand characteristics of the customer segment served, with the use of these systems more likely in higher value-added markets. Work practices correlated with customer segment include a) the type of interaction with the customer; b) the extent to which technology is used as a control device versus a resource-input; c) the skill requirements of jobs, d) discretion to influence work methods and procedures; and e) types and levels of compensation. Similarly, workforce characteristics vary along these dimensions. There is less systematic variation with respect to training, promotion, and employment security. These areas are probably more influenced by institutional factors, such as the presence or absence or unions, and by the extensive churn and restructuring that is occurring as the result of on-going deregulation.

These findings are not meant to suggest that firms in lower value-added segments are not able to adopt high involvement practices. In fact, there is some evidence that high involvement practices lead to better performance even in lower value-added segments (e.g., Batt, 1999), or in organizations such as health care that do not segment their customers (e.g., Preuss, 1997). However, the evidence does suggest that the likelihood of adoption is greater in higher value- 
added markets where cost constraints are not as great and where efficiencies based on rationalization are difficult to realize.

What are the implications of this study for other industries or other countries with distinct national institutions and business climates? First, the findings in this study are consistent with other recent studies on service sector industries. For example, Keltner and Jenson (1998) reported differentiation in human resource practices in relation to strategic segmentation in insurance and commercial banking. Hunter (1999b) found that the quality of jobs in nursing homes varied by the ability of those homes to target differentiated customer niches. The ability effectively match customer segments to human resource systems, however, is likely to vary by industry conditions. In retail banking, for example, Hunter (1999a) found no clear systems emerging because of the inability of banks to effectively segment their customer base.

Second, the use of strategic segmentation is likely to vary internationally based on the existence of distinct national preferences and institutions. As noted earlier, the U.S. telecommunications industry represents an advanced case for several reasons; but telecommunications services is a global industry in which mergers and strategic alliances across nationally-based corporations is proceeding rapidly. These partnerships provide an important vehicle for organizational learning and the transfer of practices across national institutional boundaries. Given that other countries have followed the U.S. lead with respect to deregulation and organizational restructuring, it is likely that strategic segmentation will emerge in those situations where U.S.-based multinationals have influence overseas.

Third, the findings are consistent with other research that has documented variation in work systems within industries in a number of countries. For example, in a comparative international study of the telecommunications and auto industries, Katz and Darbishire (1999) 
found the co-existence of multiple approaches to work and human resource practices within each industry in each country. Similarly, Cappelli's edited volume (1999) documents wide variation in work and employment systems within a number of U.S. industries and occupations.

Fourth, thinking of choices in management strategies and practices along a continuum is useful for several reasons. Managers in all service markets face opportunities to cut costs through greater rationalization and automated delivery, or to enhance customer loyalty through customization and relationship management. It may be that a "hybrid" model of mass customization is emerging, as suggested by Frenkel et. al. (1998) -- one in which the advantages of standardized mass production are combined with knowledge-intensive customization. Viewing work systems along a continuum allows researchers and practitioners to identify which factor dominates in each market. In the case of U.S. telecommunications, however, it appears that a true system of mass customization has yet to emerge. One the one hand, advances in automation have dominated operator services and residential markets, but few firms have been able to provide customized services at the low end. This may change as deregulation proceeds and firms develop the capabilities of offering multi-media packages to the home, but the current system does not yet resemble one of mass customization. On the other hand, for small business and middle market customers, relationship management has proceeded, but without the efficiencies of automated systems. At least for now, the complexity of services at the higher end have constrained the application of reengineering and automation. This could change with the use of E-Commerce, but firms that proceed in this direction risk losing control over their relationship with their customer.

Conceptualizing work systems along a continuum is also useful because market and organizational boundaries are fluid and constantly changing. Organizations, for example, are 
routinely seeking new ways of segmenting their customer base. A good example is in the retail market, where telecommunications companies are attempting to segment out "high end" users -those with second lines or home offices. Similarly, the small business market has ranged from "mom and pop" shops to stores with revenues of \$ 1 million. As marketing techniques become more advanced, firms are developing finer-graded approaches to segmentation. Finer market gradation will allow firms to more carefully match the characteristics of customers with those of the workforce.

In sum, how work systems in services evolve is likely to depend on managerial responses to two central forces of change -- technology and markets. On the one hand, advances in information systems will continue to evolve, and provide the opportunity to automate and rationalize increasingly complex, higher value-added services. Automation of the back office occurred in the 1960s and 1970s; automation of the front office occurred in the 1980s and 1990s. The question for the future is the extent to which process engineering can reduce costs and automate more complex services, and thereby migrate more rationalized forms of work organization into differentiated customer segments. On the other hand, customized provision of services to segmented markets suggests the need for relationship management as a competitive strategy. If competitiveness in mass markets depends increasingly on the provision of more complex bundled services -- for example, as the demand for internet services at home continues to grow -- then the current production-oriented approach may give way to greater relationship management, and with it, the need to adopt more high involvement work practices.

Finally, viewing work systems along a continuum suggests opportunities for rebuilding career ladders for service and sales workers. In telecommunications services, workers in the historic Bell system had relatively undifferentiated jobs as "service order clerks." They provided 
universal service to the public, as indicated above, in local offices where work was largely unrationalized. In the deregulated era, those workers have moved into production-oriented service centers where stress is extremely high. Consolidation of offices has often occurred in ways that relocate residential centers to one city and business centers to another -- making it difficult to pursue a career as a "customer service professional." In addition, unlike the past, a college education is increasingly the price of entry into jobs serving business clients. In an ideal world, however, customer segmentation strategies do not have to lead to segmented labor markets, with lower-skilled workers in dead-end jobs. Firms have the opportunity to reduce voluntary turnover at the low end by constructing new job ladders for customer service providers which allow them to build a career across customer segments. Firms that invest in the long-term careers of their service employees are likely to gain not only the advantages associated with strategic segmentation, but the returns on investment in high involvement work systems as well. 


\section{References}

Albrecht, K., and Bradford, L. J. (1989). The Service Advantage: How to Identify and Fulfill Customer Needs. Homewood, Ill.: Dow-Jones-Irwin.

Ames, C., and J. Hlavacek. 1989. Market Driven Management: Prescriptions for Survival in a Turbulent World. Homewood, Ill.: Dow Jones-Irwin.

Appelbaum, E., and Batt, R. (1994). The New American Workplace: Transforming Work Systems in the United States. Ithaca, NY: Cornell ILR Press.

Appelbaum, E., Bailey, T., Berg, P., and Kalleberg, A. (2000). Manufacturing Advantage. Ithaca, NY: ILR Press, an imprint of Cornell University Press.

Batt, R. (1999). "Work Design, Technology, and Performance in Customer Service and Sales.” Industrial and Labor Relations Review. 52(4):539-564.

Batt, R., and Keefe, J. (1999). "Human Resource and Employment Practices in Telecommunications Services.” In Peter Cappelli, ed., Employment Practices and Business Strategy. Oxford: Oxford University Press.

Becker, B., and Gerhart, B. (1996). "Special Research Forum: Human Resource Management and Organizational Performance.” Academy of Management Journal 39(4):777-986.

Bowen, D. E. (1986). "Managing Customers as Human Resources in Service Organizations." Human Resource Management 25(summer):371-384.

Bowen, D. E., and Schneider, B. (1988). "Services Marketing and Management: Implications for Organizational Behavior.” In B. M. Staw and L. L. Cummings, eds., Research in Organizational Behavior 10:43-80. Greenwich, Conn: JAI Press.

Bowen, D. E., and Lawler III, E. E. (1992). “The Empowerment of Service Workers: What, Why, How, and When.” Sloan Management Review 33(3)(Spring):31-39.

Bowen, D. E., and Lawler III, E. E. (1995). “Empowering Service Employees.” Sloan Management Review (Summer):73-84.

Cappelli, P., ed. (1999). Employment Practices and Business Strategy. Oxford: Oxford University Press.

Chase, R. B., and Stewart, D. (1994). “Make Your Service Fail-Safe.” Sloan Management Review (Spring): 35-44.

Czepiel, J. A., Solomon, M. R., and Surprenant, C. F., eds. (1986). The Service Encounter: Managing Employee/Customer Interaction in the Service Businesses. Lexington, Mass.: Lexington Books. 
Davenport, T. H, and Nohria, N. (1994). "Case Management and the Integration of Labor.” Sloan Management Review Winter:11-23.

Davidow, W. H., and Uttal, B. (1989). Total Customer Service: The Ultimate Weapon. New York: Harper and Row.

Day, George. 1990. Market Driven Strategy: Processes for Creating Value. New York: Free Press.

Dunlop, J., and Weil, D. (1996). "Diffusion and Performance of Modular Production in the U.S. Apparel Industry." Industrial Relations 35(3):334-355.

Dyer, L. 1985. “Strategic Human Resource Management and Planning.” In K Rowland and G. Ferris, eds., Research in Personnel and Human Resources Management 3:1-30. Greenwich, CT: JAI Press.

Fernie, S. and Metcalf, D. (2000) "(Not) Hanging on the Telephone: Payment Systems in the New Sweatshops." Forthcoming in Bruce Kaufman \& David Lewin, eds., Advances in Industrial and Labor Relations. JAI Press.

Frenkel, S., Korczynski, M., Shire, K., and Tam, M. (1999). On the Front-line: Organization of Work In the Information Economy. Ithaca, NY: Cornell University Press.

Frenkel, S., Tam, M., Korczynski, M., and Shire, K. (1998). "Beyond Bureaucracy? Work Organization in Call Centres." International Journal of Human Resource Management, 9(6): 957-979.

Greenbaum, J. (1995). Windows on the Workplace: Computers, Jobs, and the Organization of Office Work in the Late Twentieth Century. New York: Monthly Review Press.

Gutek, B. (1995). The Dynamics of Service : Reflections on the Changing Nature of Customer/Provider Interactions. San Francisco, Calif : Jossey-Bass, c1995.

Herzenberg, S., Alec, J., and Wial, H. (1998). New Rules for a New Economy: Employment and Opportunity in Postindustrial America. Ithaca, NY: Cornell University ILR Press.

Heskett, J. L. (1987). “Lessons in the Service Sector.” Harvard Business Review 65:118-126.

Heskett, J. L., Sasser, Jr., W. E., and Hart, C. (1990). Service Breakthroughs: Changing the Rules of the Game. New York: Free Press.

Heskett, J., Sasser, W. E., Jr., and Schlesinger, L. (1997). The Service Profit Chain: How Leading Companies Link Profit and Growth to Loyalty, Satisfaction, and Value. New York: Free Press. 
Hunter, L. W. (1999a). "Transforming Retail Banking: Inclusion and Segmentation in Service Work.” In Peter Cappelli, ed.,. Employment Practices and Business Strategy. Oxford: Oxford University Press.

Hunter, L. W. (1999b). "Customer Differentiation, Institutional Fields, and the Quality of Jobs in Nursing Homes." Manuscript.

Ichniowski, C., Kochan, T., Levine, D., Olson, C., and Strauss, G. (1996). "What works at work: Overview and assessment.” Industrial Relations, 35(3): 299-334.

Ichniowski, C., Shaw, K., and Prennushi, G. (1997). "The Effects of Human Resource Management Practices on Productivity: A Study of Steel Finishing Lines." American Economic Review, 87(3):291-313.

Jones, T. O., and Sasser, Jr., W. E. (1995). “Why Satisfied Customers Defect.” Harvard Business Review: 88-99.

Katz, H., ed. (1997). Telecommunications: Restructuring Work and Employment Relations Worldwide. Ithaca, NY: ILR Press, an imprint of Cornell University Press,

Katz, H. C., and Darbishire, O. (1999). Converging Divergences. Ithaca: Cornell University Press.

Keefe, J., and Batt, R. (1997). "United States." In H. Katz, (ed.), Telecommunications:

Restructuring Work and Employment Relations Worldwide. Ithaca, NY: ILR Press, an imprint of Cornell University Press, pp.31-88.

Keltner, B. (1995). "Relationship Banking and Competitive Advantage: Evidence from the U.S. and Germany." California Management Review 37(4)(Summer): 45-73.

Keltner, B. (1998). "Strategic Segmentation in Services." Manuscript. May.

Keltner, B., and Jensen, B. (1998). "Segment Strategies and the Resource-Based View of the Firm." Manuscipt.

Keltner, B. and Finegold, D. L. (1996). “Adding Value in Banking: Human Resource Innovations for Service Firms.” Sloan Management Review 38(1) Fall.

Kohl, G. 1993. "Information Technology and Labor: A Case Study of Telephone Operators." Workplace Topics 3 (1): 101-111.

Kotler, P. 1994. Marketing Management: Analysis, Planning, and Control. Englewood Cliffs, NJ: Prentice-Hall. Fifth Edition. 
Lawler, E. E. III, Mohrman, S., and Ledford, G. (1995). Creating High Performance Organizations: Practices and Results of Employee Involvement and Total Quality Management in Fortune 1000 Companies. San Francisco: Jossey-Bass.

Leidner, R. (1993). Fast Food, Fast Talk: Service Work and the Routinization of Everyday Life. Berkeley: University of California Press.

Levitt, T. (1972). “Production Line Approach to Services.” Harvard Business Review. 50(5):41-50.

Levitt, T. (1976). “The Industrialization of Service.” Harvard Business Review. 54(5):63-74.

Liker, J. K., Fruin, W. M., and Adler, P. S., eds. (1999). Remade in America: Transplanting and Transforming Japanese Management Systems. Oxford: Oxford University Press.

Lovelock, C. H. (1988). Managing Services: Marketing, Operations, and Human Resources. Englewood Cliffs, NJ: Prentice Hall.

Mills, P. K. (1986). Managing Service Industries: Organizational Practices in a Post-Industrial Society. Cambridge, Mass.: Ballinger.

Mills, P. K., Chase, R. B., and Margulies, N. (1983). “Motivating the Client/Employee System as a Service Production Strategy.” Academy of Management Review 8:301-310.

Monthly Labor Review. (1998). Current Labor Statistics: Labor Force Data. 121(6): June.

National Research Council. (1994). Information Technology in the Service Sector: A 21st Century Lever. Washington, D.C.: National Academy Press.

Osterman, P. (1994). “How Common is Workplace Transformation and Who Adopts It?” Industrial and Labor Relations Review 47(2):173-188.

Osterman, P. (2000). "Work Organization in an Era of Restructuring: Trends in Diffusion and Impacts on Employee Welfare." Industrial and Labor Relations Review. January.

Pine, B. (1993). Mass Customization. Cambridge, MA: Harvard Business School Press.

Pine, B. J., Victor, B., and Boyton, A. C.. (1996). "Making Mass Customization Work.” Harvard Business Review September-October:108-120.

Pfeffer, J. (1998). The Human Equation. Cambridge: Harvard Business School Press.

Preuss, G. (1997). "Managing Care: Restructuring of Work in Hospitals: An Examination of Hospital Care." Academy of Management Best Paper Proceedings. Georgia Southern University. 
Quinn, J. B., and Paquette, P.C. (1990). “Technology in Service: Creating Organizational Revolutions.” Sloan Management Review 67-78.

Reichfeld, F., and Sasser, W. E. (1990). “Zero Defections: Quality Comes to Services.” Harvard Business Review September-October: 105-123.

Reichheld, F. (1996). The Loyalty Effect. Boston: Harvard Business School Press.

Roach, S. (1991). “Services Under Siege-The Restructuring Imperative.” Harvard Business Review :82-91.

Schlesinger, L., and Heskett, J. (1991). “Breaking the Cycle of Failure in Services.”_Sloan Management Review 32(Spring):17-28

Schlesinger, L., and Zornitsky, J. (1991). “Job Satisfaction, Service Capability, and Customer Satisfaction: An Examination of Linkages and Management Implications. Human Resources Planning 14(2): 141-149.

Schneider, B., and Bowen, D. E. (1995). Winning the Service Game. Harvard Business School Press.

Schuler, R. S., and Jackson, S. E. (1987). "Linking Competitive Strategies with Human Resource Management Practices.” Academy of Management Executive 1(3):207-219.

Taylor, P., and Bain, P. ((1999)). "'An Assembly Line in the Head': Work and Employee Relations in the Call Centre." Industrial Relations, 30(2).

Truss, C., and Gratton, L. (1994). "Strategic Human Resource Management: A Conceptual Approach." International Journal of Human Resource Management, 5(3): 663-686.

Ulrich, D. (1989). “Tie the Corporate Knot: Gaining Complete Customer Commitment.” Sloan Management Review 30(Summer):19-27.

Ulrich, D., Halbrook, R., Meder, D., Stuchlik, M., and Thorpe, S. (1991). "Employee and Customer Attachment: Synergies for Competitive Advantage.” Human Resources Planning 14(3): 89-103.

Weiser, C. R. (1995). “Championing The Customer.” Harvard Business Review: 113-116.

Whitely, R. 1991. The Customer Driven Company: Moving from Talk to Action. Reading, MA: Addison-Wesley.

Womack, J., Jones, D., and Roos, D. (1990). The Machine That Changed the World. New York: Rawson Associates. 
Zeithaml, V. A., Parasuraman, A., and Berry. L. L. (1990). Delivering Quality Service: Balancing Customer Perceptions and Expectations. New York: Free Press.

Zemke, R., and Schaff, D. (1989). The Service Edge: 101 Companies That Profit from Customer Care. New York: NAL Books.

Zimmerman, C., and Enell, J. (1988). “Service Industries.” In J. M. Duran and F. Gryna, eds., Juran's Quality Control Handbook. Fourth Edition. New York: McGraw Hill, pp. 33.1-72. 
${ }^{1}$ First because services are produced and consumed at once, there are no opportunities for postproduction quality control, heightening the importance of first time quality. Moreover, because services often involve multiple contacts or transactions, there are multiple opportunities for bad service; one mistake has a longer lasting effect than one positive interaction (Zimmerman and Enell, 1988). Second, because customers participate in production, they have been conceptualized as "partial employees" (Mills, Chase, and Margulies, 1983); management has the opportunity (or requirement) to manage customer expectations and behavior and to gain flexibility and externalize some production costs to customers (as in self-service operations). Third, the intangible and perishable nature of services makes it more difficult to develop accurate performance measurement systems. Measurement usually relies on the byproduct of a service (paper or data trail, survey feedback), rather than observation (Zimmerman and Enell, 1988). A related argument is that it is more difficult to separate or "buffer" one function from another in services: by definition, customer contact employees represent the strategy of the firm, and perform production and marketing at once, even when management does not formally organize work in ways to take advantage of this fact (Riddle, 1990).

2 Articles in the Harvard Business Review included: Heskett, 1987; Roach, 1991; Reichheld and Sasser, 1990; Jones and Sasser, 1995; Weiser, 1995; Pine, Peppers, and Rogers, 1996; Pine, Victor, and Boyton 1996. Those in the Sloan Management Review included Ulrich, 1989; Quinn and Paquette, 1990; Schlesinger and Heskett, 1991; Bowen and Lawler, 1992, 1995; Chase and Stewart, 1994; Davenport and Nohria, 1994; Keltner and Finegold, 1996.

${ }^{3}$ Note that the percent of the workforce that is unionized is much larger in each case because larger establishments are more likely to be unionized. Thus, in this sample, 39 percent of employees in residential services are unionized and 46 percent of operators belong to unions, but only 8 percent of middle market representatives. 
Figure 1: Strategic Segmentation \& High Involvement

\section{Customer}

segment

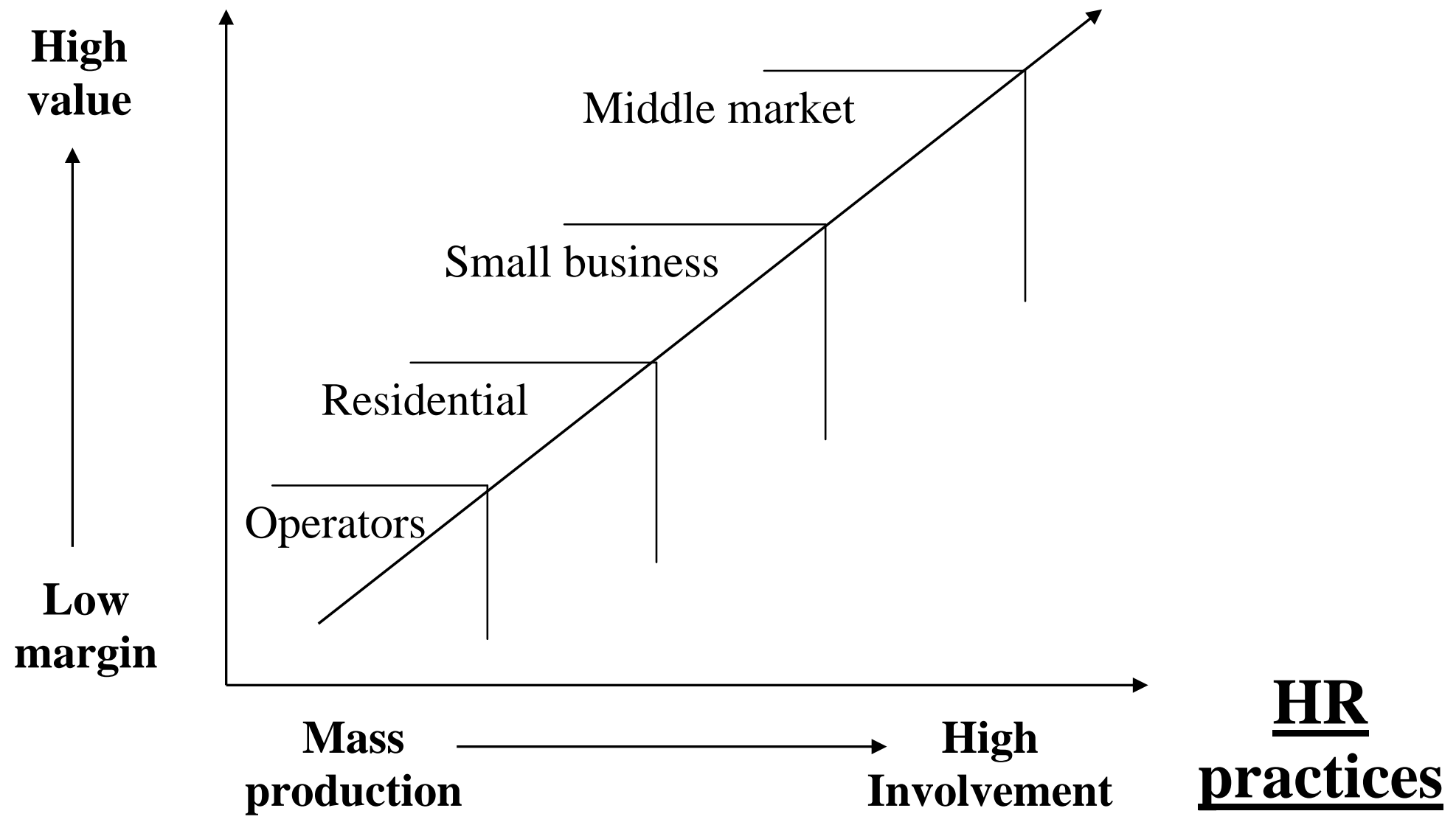


Table 1:

The Organization of Service Work:

The Customer-Employee Interface

$\begin{array}{ccccc}\text { Operator } & \text { Residential } & \text { Small } & \text { Middle } & \text { Sig: } \\ \text { Services } & \text { Consumers } & \text { Business } & \text { Market } & \mathbf{p}<.05\end{array}$

\section{Direct Customer-Employee Interaction}

Customers per employee per day

$\%$ face-to-face interactions

Ave. minutes per customer call

$\%$ use of "scripted texts"*

\section{Technology-Mediated Interaction}

$\%$ completed transactions on-line

$\%$ time electronically monitored

No.software programs used

No. emails per employee per day

Discretion in Handling Customers

Types of customers served*

How many customers to serve*

\section{Organizational Characteristics}

Customer base

\# of customers per employee

$\%$ whose market is international

\section{5}

5.4

0.9

52.9

92.8

82.6

66.2

1.2

2.9

11.8

0.0

5.8

18.2

100

19.1

6.0

8.7

73.6

76.5

48.7

3.6

10.1
352,343

144

1,744

17.6

81.6

35.3

17
$\%$ time on computer \& phone

Size of workforce

818,977
503
11,539
3.8

157,772

192

124,134 c,d

4,112

190

2,139

5.8

22.4

$16.2 \mathrm{~d}$

56.4 a,d

,b,c,d

20.7 a,b,c,d

6.7 a,d

19.8 a,b,c,d

\section{Employee Characteristics}

$\%$ female

$\%$ unionized

Sample Size

$$
72.2
$$

21.9

59.5

12.8

107

86
45.8 a,b,c,d

4.4 a,d

* The percent answering 4 or 5 ("a lot" or "complete") on a scale of 1-5.

$\mathrm{a}=$ residential and middle market are significantly different at $\mathrm{p}<.05$.

$\mathrm{b}=$ residential and small business are significantly different at $\mathrm{p}<.05$.

$\mathrm{c}=$ small and middle market are significantly different at $\mathrm{p}<.05$.

$\mathrm{d}=$ operators significantly different than residential, small business, \& middle market at $\mathrm{p}<.05$. 
Table 2

The Organization of Service Work:

Skills, Discretion, and Team Participation

\section{Skill Level}

Education level (years)

Weeks to become qualified

$\%$ who are exempt from U.S. wage

and hour laws

Discretion Over Work Methods:

Daily tasks \& assignments*

Tools \& procedures*

Pace \& speed at work*

Setting work objectives*

Revising work methods*

Setting lunch \& rest breaks*

Setting vacation schedules*

Design \& use of technology* $\begin{array}{ccccl}\text { Operator } & \text { Residential } & \text { Small } & \text { Middle } & \text { Sig: } \\ \text { Services } & \text { Consumers } & \text { Business } & \text { Market } & \mathbf{p}<.05\end{array}$

$\begin{array}{rrrrl}12.4 & 13.0 & 13.7 & 15.2 & \text { a,b,c,d } \\ 13.0 & 17.0 & 22.1 & 27.5 & \text { a,d } \\ 0.0 & 12.9 & 26.2 & 75.8 & \text { a,c,d }\end{array}$

\section{Participation in Teams}

$\%$ who use "offline" problem-solving

$\%$ penetration in offline teams

$\%$ who use self-managed teams

$\%$ penetration of self-managed teams

\section{Sample Size}

23.5

23.5

23.5

0.0

17.7

11.8

64.7

0.0
34.3

23.8

23.8

14.3

23.8

21.0

47.6

4.8
46.5

30.2

43.0

15.1

22.1

46.5

62.8

7.0
63.2 a,d

49.3 a,d

61.2 a,b,c,d

16.2 a,d

30.9 a

82.4 a,b,c,d

72.1

17.7 a,d

* The percent answering 4 or 5 ("a lot" or "complete") on a scale of 1-5.

$\mathrm{a}=$ residential and middle market are significantly different at $\mathrm{p}<.05$.

$\mathrm{b}=$ residential and small business are significantly different at $\mathrm{p}<.05$.

$\mathrm{c}=$ small and middle market are significantly different at $\mathrm{p}<.05$.

$\mathrm{d}=$ operators significantly different than residential, small business, \& middle market at $\mathrm{p}<.05$. 
Table 3:

Incentives: Pay, Training, Promotion, and Employment Security

$\begin{array}{ccccc}\text { Operator } & \text { Residential } & \text { Small } & \text { Middle } & \text { Sig: } \\ \text { Services } & \text { Consumers } & \text { Business } & \text { Market } & \mathbf{p}<.05\end{array}$

\section{Compensation}

Median annual base pay

19,382

1,346

17.2

Median annual benefits costs

Total compensation

$\%$ pay that is variable

\section{Training}

Weeks of initial training

Weeks of on-going training/year

\section{Promotion}

$\%$ promoted from within

$\%$ with $<1$ year of tenure

$\%$ with $>10$ years of tenure

\section{Employment Security}

$\%$ workforce: temporary

$\%$ workforce: part-time

$\%$ workforce: perm.fulltime

$\%$ laid off in prior 2 years

\section{Sample Size}

2.0

25.5

35.2

0.4

17.6

82.1

28.4

17

$\begin{array}{rrrl}27,271 & 34,786 & 61,603 & \text { a,b,c,d } \\ 1,764 & 1,674 & 339 & \text { c } \\ 24.5 & 26.0 & 26.7 & \\ 35,708 & 45,504 & 78,390 & \text { a,b,c,d } \\ 13.69 & 26.83 & 34.76 & \text { a,b,c,d }\end{array}$

4.7

3.9

4.9 a,

1.1

2.0

1.8

$2.3 \quad \mathrm{a}$

37.6

33.7

44.3

31.2

31.4

26.9

32.6

22.9

29.8

a,b,c

5.4

3.1

$0.6 \quad \mathrm{c}$

9.8

9.5

$3.8 \quad \mathrm{c}, \mathrm{d}$

86.1

87.8

26.2

11.0

95.4 a,c,d

107

86

68

$\mathrm{a}=$ residential and middle market are significantly different at $\mathrm{p}<.05$.

$\mathrm{b}=$ residential and small business are significantly different at $\mathrm{p}<.05$.

$\mathrm{c}=$ small and middle market are significantly different at $\mathrm{p}<.05$.

$\mathrm{d}=$ operators significantly different than residential, small business, \& middle market at $\mathrm{p}<.05$. 